\title{
Exploring the Factors Perceived to be Inhibiting the Realisation of the Objectives of the Ghana Alternative Market (GAX)
}

\author{
Emmanuel Acquah-Sam, PhD \\ Wisconsin International University College, Ghana
}

Doi:10.19044/esj.2019.v15n31p124 URL:http://dx.doi.org/10.19044/esj.2019.v15n31p124

\begin{abstract}
The Ghana Alternative Market (GAX) was established in 2013 to provide equity financing avenue for the development of SMEs and startups in Ghana. However, after six years of its establishment, the market is still unable to attract adequate listing of SMEs and startups. This study explored the factors perceived to be inhibiting the realisation of the objectives of the GAX, and its target of listing fifty firms by the end of 2020. Frequency distribution, bivariate correlations and multiple regression techniques were explored in this study. The correlation analysis shows that "extent of objective realisation" is significantly associated with "achievement of target by the end of 2020", "perceived importance" of GAX, and "inadequate information" on GAX, but is not correlated significantly with the other variables at $5 \%$ level of significance. The regression analysis revealed that fear of failure of small and medium businesses and startups and the low-income situation of prospective investors make negative influences on the degree to which the objective of GAX could be met. Thus, the degree to which the objective of GAX is met decreases as investors' fear of failure and low-income situations increase. Taken into consideration the fact that only five (5) companies have been listed on the GAX since its inception, and the fact that only a few months remain till the end of 2020, it seems very difficult for the authorities of GAX to attain its target of listing 50 firms by the end of 2020. It is recommended that more time and efforts are needed for the realisation of its objectives. The officials of Ghana Stock Exchange (GSE) and GAX must intensify education on the sector to boost the confidence of owners of SMEs and startups in the operations of the sector. Again, the government of Ghana must improve economic conditions in Ghana to increase the real incomes of workers in Ghana so as to help more people buy securities of listed SMEs and startups. The costs and requirements for listing on the GAX must be scaled down further. The government of Ghana must find the possibility of synchronising the activities of National Entrepreneurship and Innovation Plan (NEIP),
\end{abstract}


Microfinance and Small Loans Centre (MASLOC) and GAX to reduce duplication of efforts and to ensure efficient allocation of financial resources to SMEs and startups in Ghana.

Keywords: Ghana Stock Exchange (GSE), Ghana Alternative Markets (GAX), Small and Medium Enterprises (SMEs), Startups, and Multiple Regression Analysis

\section{Introduction}

Small and Medium-Sized Enterprises (SMEs) have different definitions and classifications throughout the world. A country's classification of a company as an SME can be based on annual sales, number of employees, the amount of assets owned by a company, or any combination of these features. SMEs constitute the majority of the businesses operating around the world. Generally, they are independent firms with no less than fifty (50) employees. However, the maximum number of employees differ from one country to another. The upper range of employees for most companies is around two hundred and fifty (250). Some countries fix the total number of employees at two hundred (200). The United States defines an SME, among other characteristics, as having no more than 500 workers. In Canada, SMEs are businesses that have fewer than 500 employees. (https://corporatefinanceinstitute.com/resources/knowledge/other/small-andmedium-sized-enterprises-smes/).

Majority of the enterprises around the world are small and medium in nature irrespective of the level of development of an economy. SMEs contribute immensely to economic growth through output growth, employment creation, and tax revenue generations by governments for infrastructural development. In 2002, the World Bank (2002) reported that in Australia, SMEs provided $35.7 \%$ of the total jobs. In Hong Kong, China, SMEs provided $58.4 \%$ of the total jobs and contributed $53.8 \%$ to total output. In Spain, SMEs provided $67.5 \%$ of the total jobs. In the United Kingdom, SMEs provided $42.1 \%$ of the total employment and contributed $19.5 \%$ to total output.

For SMEs and startups to offer their numerous benefits to societies, they need to grow overtime. As firms grow, they enjoy benefits that cement their continual existence. The objectives of firms are many and reflect the organisational structures and incentives built into their systems. Some firms consider growth as a way of survival in the long run. It is believed that when firms remain in their present small states they, may be taken over by larger firms. For some firms too, the objective of growth is to reap higher profits. This results from the fall in the unit costs of production, increased market share, and the ability to control the prices of their products. 
Despite the benefits offered by SMEs and startups, many of them fail to grow. This has been attributed to institutional and financial constraints. The financial health of a firm will determine its ability to fund its growth. Usually, lack of funds limit the ability of firms to grow since money is what is used to buy the necessary inputs and technology required for growth. Sitharam \& Hoque (2016) investigated the factors affecting the performance of SMEs in KwaZulu-Natal, South Africa and reported that technological advancement would improve the performances of businesses in the area. With regards to challenge, competition was the major one. Also, crime and corruption affected business performance. Competition was the only factor among the studied internal and external factors that revealed a significant association with the performance of SMEs in KwaZulu-Natal.

Growth of business firms can be financed through Borrowing - this is influenced by interest rates and credit worthiness of firms, Retained earnings - this is the proportion of profits that is ploughed back into business in the form of investments, and Issuance of shares to internal shareholders and the general public. The ability of firms to raise capital through issuance of shares depends on public confidence in the operations of the stock market and the current and future performance of the firms involved. Many firms in an attempt to address their financial challenges so as to grow have resorted to either the capital market or banks to raise funds for investments projects. Companies looking to access external finance necessarily consider the associated costs and benefits of a particular financing option. Demirgüç-Kunt \& Maksimovic (1996) empirically analysed the effects of stock market development on firms' financing choices and reported that initial improvements in the functioning of a developing stock market produced a higher debt-equity ratio for firms and thus more business for banks. In stock markets that are already developed, further development leads to a substitution of equity for debt financing. Thus, in developing stock markets, large firms become more levered (That is, they use more debt or borrowed funds to finance projects and investments). The functioning of an equity market will have three direct effects on the firm's debt-equity ratio. First, a substitution effect occurs as outside equity is substituted for outside debt by firms that had previously been constrained to issue only outside debt. This effect will decrease the firm's debt-equity ratio. Second, outside equity will be substituted for inside equity. This will not affect the firm's debt-equity ratio. Third, the entrepreneur's ability to diversify risks may make expansion more attractive. The effect of such expansion on the firm's debt-equity ratio is ambiguous and will depend on the optimal financial structure of the firm.

The Organisation for Economic Co-operation and Development (2016) report emphasises that in spite of the recent improvements in SMEs lending, many SMEs continue to face credit 
constraints. Though much focus has been on enhancing lending to SMEs, there is growing emphasis on the need to diversify the range of financing options that are available to SMEs and consequently the potential role of capital markets in SMEs' financing. This is partly attributed to the decline in bank lending after financial crisis, and the recognition of the negative effect overreliance on debt finance can have on the ability of firms to withstand economic downturns.

In Ghana, majority of businesses are in the SME category. As a result, almost all the financial institutions in Ghana, including banks, savings and loans, microfinance, and money-lending businesses (SUSU) have over the years created desks for SME businesses. There are government institutions earmarked for advancing credit facilities to SMEs and Startups. The sad truth is that some of these funds allocated to SMEs and startups are not accessed, due in part to high interest rates on them, and lack of integrity on the part of some SME owners.

Over time, it was realised that the Ghana Stock Exchange (GSE) could not provide SMEs and Startups with relatively cheap long-term funds because of the regulations governing the operations of the main exchange. As part of the effort of the government of Ghana and the regulators of the GSE to address the problem of inadequate funds for SMEs and Startups, the GSE established the GAX. GAX focuses on businesses with potential for growth. That is, companies at various stages of their development, including Startups and existing enterprises, both small and medium. Listing on the GAX is aimed at promoting easier access to long term capital at a relatively lower cost, improvement in the financial positions of GAX companies, enhanced status in the community, realisation of value of investments, reduce risk, improved liquidity, and mandatory underwriting of the minimum offer directly or indirectly by sponsor.

On April 24, 2018, the Business and Financial Times reported a speech delivered by Mr. David Tetteh, a consultant to the Ghana Stock Exchange (GSE) and Ghana Alternative Market (GAX), in which he told participants that managers of GAX sought to get more indigenous businesses to list on the market and was hopeful that the target of getting fifty (50) businesses to list on GAX by the end of 2020 was still on course. However, since its inception, only five companies have taken advantage of the GAX by listing on it. Again, Tetteh (2014) investigating why GAX had not attracted any listings, almost one year after its establishment in May 13, 2013, interviewed only two officials of GAX, but focused on owners and operators of SMEs to discover their willingness to list on GAX. The weaknesses in the work of Tetteh (2014) which prompts further studies into the sector are twofold: (i) Eleven months into the launch of GAX was not long enough to provide any significant results. (ii) Seeking opinions of two officials of GAX could not provide sufficient 
information for appropriate recommendations to be made to address the challenges of the market.

The researcher has noticed that there is not enough studies in the area to provide sufficient light on its path. Also, investor participation in the market is nothing to write home about. In a broader picture, many of the exchanges on the African continent are still struggling with the problem of attracting listings of SMEs despite the creation of SME boards (ASEA, 2017). Also, equity markets in Asia, except for those in the People's Republic of China (PRC) and the Republic of Korea, have not yet become a financing source for SMEs and startups (Shinozaki, 2014). These problems require extensive national policies and strategies for improved SMEs' access to capital markets.

This paper, therefore, deemed it important to seek the views of the officials of GAX, GSE, and Securities and Exchange Commission (SEC) and brokerage firms to find out whether the perceived target and objectives of GAX were achievable, and to explore the factors that would inhibit the realisation of the target and the overall objectives of GAX so as to provide recommendations for policy-decisions and to widen the scope of literature on GAX.

The remaining sections of the paper are as follows: Section 2 looks at the literature review (the theoretical, empirical, conceptual framework, importance of SMEs and start-ups, effects of equity financing on business firms, and background of the GAX). Section 3 is about the methodology explored in the study. Section 4 details the findings of the study. Section 5 presents the summary, conclusions, and recommendations emanating from the study for policy decision-making and for future studies. The supporting references conclude the paper.

\section{Literature Review}

Calderon-Rossell (1991) was the first to develop a model to determine stock market growth. However, the model failed to account for the likely effects of government policies and institutional factors on stock market growth. Generally, available literature indicate that "macroeconomic factors" and "institutional factors" are the two main factors affecting the development of both stock and financial markets. Macroeconomic factors include the level of economic development, Gross Domestic Product (GDP) growth, inflation, exchange rates, interest rates, and capital flows. Institutional factors include variables that reflect the role and state of regulatory and supervisory institutions such as legal frameworks and the protection of property rights. Both macroeconomic factors and institutional factors are interrelated, in that, the evolution of the institutional environment is directly reflected in macroeconomic conditions. Similarly, a favourable macroeconomic 
environment facilitates the development of institutions (Adarov and Tchaidze, 2011; cited in El-Wassa, 2013).

El-Wassa (2013) proposes supply factors, demand factors, institutional factors and economic policies as determinants of stock market development. Demand factors are those that affect investors' decisions regarding investment in stock markets while supply factors are those that affect companies' decisions to issue shares. Taken together, both sets of factors serve as "building blocks" of the stock market. Yet, the existence of supply and demand alone cannot guarantee the existence of a developed stock market and these must be combined with institutional factors and economic policies. Well-established institutions and the implementation of appropriate economic policies are conducive to investor confidence and the development of stock markets. Three principles concerning stock market development are worth highlighting. First, stock market development is a difficult, complex, multifaceted, and long-term process. For investors, shares are the riskiest of the standard financial assets while for companies, issuing shares is the costliest way to raise funds. As a result, stock market development may take a long time. Secondly, stock market development is a part of a process of development of a financial system. A stock market cannot be developed in the absence of a financial system that is both developed and balanced. Third, though the development of a stock market is primarily a private sector activity, the supporting role of the government is crucial for a market to develop. The experience of stock markets in developed countries shows that the development of a stock market cannot be isolated from solid institutional structures.

\subsection{Conceptual Framework}

Figure 1 below illustrates how the factors perceived to have effect on the extent to which the objectives and targets of the Ghana Alternative Market (GAX) can be realised. We identify nine (9) factors that when not properly addressed by stakeholders of the GAX will hinder GAX from realising its objectives and targets. The factors are: Perceived unimportance of GAX by owners of SMEs and Startups as an important avenue to raise financial capital for business investments and growth; low or moderate level of investor participation in the GAX; prospective investors' fear of failure of SMEs and Startups; lack of transparency and owners' mismanagement of SMEs and Startups; low incomes of prospective investors; domestic macroeconomic factors offering disincentives to prospective investors to buy GAX securities; inadequate information or lack of awareness of the existence of the GAX among prospective investors; unattractive returns on GAX securities; and prospective investors' preferences for alternative investment opportunities 
(Treasury Bills, Fixed Deposits, Real Estate, Savings, Insurance, Agriculture, Transportation, etc.).

It is perceived that improvements in these factors, other things being equal, should have positive influences on the growth and the realisation of the objectives of the GAX. The extent to which these factors explain stock market development are explained under the methodology section of this study.

Figure 1. Factors Perceived to Inhibiting the Realisation of

Target and Objectives of the GAX

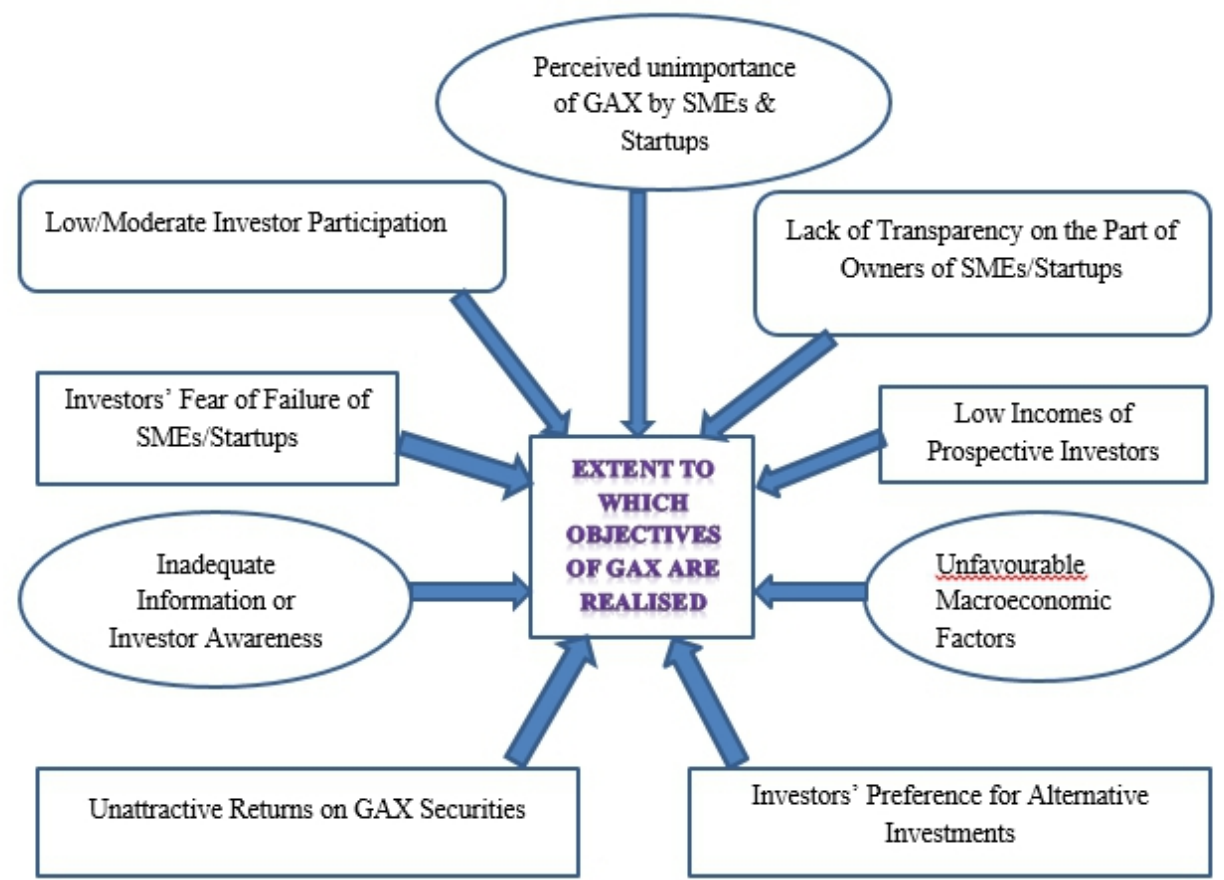

Source: Researcher's Own Design (2019)

\subsection{Small and Medium-Size Enterprises (SMEs)}

The role of Small and Medium Enterprises (SMEs) in economic development of countries has received special attention in recent times. The differences in SME definitions across countries can make an international comparison ambiguous. It is therefore imperative that in any study on SMEs, the definition of SME in the jurisdiction in which the study is being carried out is considered.

Small and Medium Enterprises represent $99 \%$ of all businesses in the European Union (EU). The European Commission considers SMEs and entrepreneurship as key to ensuring economic growth, innovation, job creation, and social integration in the EU. Small firms form a chunk of the enterprises throughout the world regardless of their geographical locations or level of development. 
SMEs are non-subsidiary, independent firms which employ less than a given number of employees depending on the country of establishment. In the European Union, the most frequent upper limit designating an SME is 250 employees. However, some countries set the limit at 200 employees. In the United States, SMEs include firms with less than 500 employees. Small firms are generally those with less than 50 employees, while micro-enterprises have at most 10, or in some cases, 5 workers. Financial assets are also used to define SMEs. In the European Union, a new definition came into force on $1^{\text {st }}$ January, 2005 applying to all Community Acts and Funding Programmes as well as in the Field of State Aid where SMEs can be granted higher intensity of national and regional aid than large companies. The new definition provides for an increase in the financial ceilings: the turnover of medium enterprises (50-249 employees) should not exceed EUR 50 million; that of small enterprises (1049 employees) should not exceed EUR 10 million while that of micro firms (less than 10 employees) should not exceed EUR 2 million. Alternatively, balance sheets for medium, small and micro enterprises should not exceed EUR 43 million, EUR 10 million and EUR 2 million respectively (OECD, 2005).

Bolton Committee Report (1971 cited in Griffiths \& Walls, 1995) defined small firms as those with more than two hundred (200) employees. However, it was practically found to be inadequate, so the committee suggested that a definition of small firms should consider those characteristics of small firms which might be expected to make their performances and their problems significantly different from those of large firms. They concluded in this wise that, three main characteristics had to be taken into account. These are:

a) A small firm is one that has a relatively small share of its market.

b) It is managed by its owners or part owners in a personalised way and not through the medium of a formalised management structure.

c) It is independent in the sense that it does not form part of a large enterprise, so its owner-managers are free from outside control when taking their principal decisions.

The above characteristics formed the "economic" definition of the small firm. The Committee later found that for statistical purposes, the criteria for a small firm would have to vary from sector to sector.

- In manufacturing, a small firm must have 200 employees or less. In construction and mining, the upper limit for a small firm was reduced to 25 or less.

- In the motor trades, retailing, and miscellaneous services, the statistical definition was based not on the number of employees, but on a specified upper limit for annual turnover. Example, $£ 200,000$ for motor trades and $£ 50,000$ for retailing and miscellaneous services. 
- In road transport the definition was based on the number of vehicles operated. The number of vehicles operated was to be less than five (5).

\subsection{Importance of SMEs and Startups}

The attention that is paid to the activities of small firms in recent years stem from the fact that they offer numerous benefits to societies that promote social and economic development all over the world and for these reasons many people have touted them as the engine of economic growth. Among the benefits they offer are:

i. Employment creation: SMEs and startups offer a lot of job opportunities to people. They address the problems of poverty, inequality, and job creation in rural areas. They are important sources of employment, especially for women, low skilled workers and the youth. In Australia, SMEs offered $35.7 \%$ of the total jobs, whiles in Hong Kong, China they offered $58.4 \%$ and contributed $53.8 \%$ of the total output. In Spain, it was found to have offered $67.5 \%$, and in the United Kingdom (UK) they contributed $42.1 \%$ to employment, and $19.5 \%$ to total output (World Bank, 2002). Edmiston (2004) also adds that the Census Bureau data of USA show the bulk of net new jobs created are generated by firms with fewer than 20 employees. Net new jobs is the total number of new jobs created by Startups firms and expansions (gross job creation) less the total number of jobs destroyed by firm closures and contractions (gross job destruction). Firms with less than 20 employees (small firms) contributed 69\% of net new jobs over the 1990-2001 period, despite accounting for less than $18 \%$ of total employment in 2001. Firms with 20-499 employees accounted for $10 \%$ of net new jobs over the period, while firms with 500 or more employees (large firms) created $21 \%$ of net new jobs. It is believed that new businesses will not only create jobs in the local community, but through innovation, may also have the potential to grow into larger firms that can provide numerous jobs and become the industry leaders in the future. On the continent of Africa, SMEs create close to $80 \%$ of the continent's employment, and have contributed to the development of a new middle class that is in turn fuelling demand for goods and services.

ii. Growth of Gross Domestic Product (GDP): GDP is the monetary value of all finished goods and services produced by the numerous firms in a country in a particular year. Small businesses dominate the bulk of an economy's output of goods and services.

iii. Tax revenue generation: The taxes on profits and salaries of employees of SMEs and Startups paid to governments contribute to the total tax revenues of countries. These taxes are used for infrastructural development and improvement in the lives of the citizenry. 
iv. Greater efficiency: The theory of perfect competition suggests that markets that are dominated by small firms produce economic, productive, technical, and allocative efficiencies. That is, they produce outputs with the lowest average costs as a result of optimal inputs combination. They provide benefits to consumers at the margin. That is consumers' marginal benefits are equal to the marginal costs of production (Price $=$ Marginal cost).

v. Facilitating innovation: The ingenuities of the SMEs and startups contribute to the foundation of industrial revolution. In capitalism, therefore, the only survivors are those who constantly innovate and develop new products and processes to replace the old ones. SMEs and Startups undertake research and development into their economic activities that lead to products and process innovations that increase the range of consumer choices and improve the quality of what they produce. Thus, they promote technological research and development that improve welfare of consumers. Brown \& Latour (2004, cited in Edmiston, 2004) write that Joseph Schumpeter asserted that the hallmark of capitalism is innovation: The sweeping out of old products, old enterprises, and old organisational forms by new ones, to which he referred as a process of "creative destruction.

vi. SMEs and startups rely on internally supplied resources and governance issues that are much simpler than in large firms. Decision-making is made easier and that maximises production and consumption. They are presumed to be more flexible and, therefore, better able to adapt to changing market conditions.

\subsection{Measures to Promote the Growth of SMEs and startups}

Nkuah, Tanyeh \& Gaeten (2013) write that a survey by the Association of Ghana Industries (AGI) for the second quarter of 2011 showed that lack of adequate access to credit was ranked highest among the factors hindering the growth of SMEs and startups in Ghana. They further report that there exists significantly positive relationship between financial activities (such as business registration, documentation/recording, business planning, and asset ownership) and SMEs startups' access to bank credits. To ensure sustainable growth in output and employment, government policies have paid special attention to SMEs and startups. Among the measures that continue to be put in place are:

a) Equity and loan capital: Equity and loan capital include the Enterprise Investment Scheme (EIS), loan guarantee scheme where government agencies contract loans for Equity and loan capital which lack collateral. A 2016 OECD report reveals that despite recent improvements in SMEs lending, many SMEs continue to face credit constraints. While much of 
the focus is on enhancing lending to SMEs, there is growing emphasis on the need to diversify the range of financing options that are available to SMEs and consequently the potential role of capital markets in SMEs financing. This is partly a consequence of the retreat in bank lending because of financial crises and lack of integrity on the part of owners of SMEs and startups that make them default on loan repayments. In addition, the use of equity finance is as a result of the recognition of the negative impact that an over-reliance on debt finance can have on the ability of firms to withstand economic downturns.

Across Africa, more than $70 \%$ of SMEs cease to exist within five years and in some countries, the failure rate is as high as 90\% (Collier, 2014) Though some of the causes of their failure may be inherent to creative destruction, there are also internal and external factors that hinder SMEs' growth potential. African Securities Exchanges Association (ASEA) has established a working group called the ASEA SME Facilitation Working Group since 2017 in order to proactively explore financing options for SMEs through African Capital Markets. The group is tasked to engage and collaborate with various stakeholders such as the African Development Bank (AfDB) to propose viable opportunities to raise capital for SMEs on ASEA member stock exchanges. In this wise, many of the exchanges have SME boards on their exchanges. The SME board is a segment of the stock exchange set aside for trading the shares/ securities of SMEs, who otherwise find it difficult to get listed on the main bourse. The SME boards typically have less listing requirements than the requirements for listing on the main board. Among the common reasons for SMEs to list on exchanges include: finance, corporate governance, profiling, infrastructure development, and learning and skills development (ASEA, 2017). However, many of the exchanges are still struggling with the problem of attracting listings of SMEs and Startups.

Shinozaki (2014) writes that in emerging Asia, equity financing venues for SMEs have been mostly created under stock exchange operations. In the People's Republic of China (PRC), the Shenzhen Stock Exchange (SZSE) has developed a three-tier market venue comprising the Main Board, SME Board (May 2004), and ChiNext (October 2009) in line with national economic development strategies. Hong Kong, China's Growth Enterprise Market (GEM) is an alternative stock market for high-growth enterprises operated by the Stock Exchange of Hong Kong Ltd. India has recently developed dedicated stock exchanges for SMEs following the recommendation of the Prime Minister's Task Force in June, 2010. The Bombay Stock Exchange (BSE) launched the SME Exchange in March, 2012 and it has 41 listed SMEs as of $19^{\text {th }}$ November, 2013. The National Stock Exchange (NSE) has also launched the SME platform named 
Emerge, with 3 listed SMEs. KOSDAQ is the largest organized market for SMEs and venture businesses in the Republic of Korea and is operated by the Korea Exchange (KRX). As KOSDAQ is becoming a funding venue for high-end larger enterprises, a new market designed for SMEs named KONEX was launched under KRX in July, 2013. MESDAQ under Bursa Malaysia was re-launched as the ACE (Access, Certainty, and Efficiency) market in August, 2009, a sponsor-driven alternative market. Catalist in Singapore is a Singapore Exchange (SGX)-regulated but sponsorsupervised market for rapidly growing enterprises, modeled on the UKAIM (December, 2007). The Securities Exchange of Thailand (SET) has operated the market for alternative investment (mai) since June, 1999, targeting SMEs as potential issuers. Working Paper Series on Regional Economic Integration No. 121 equity markets for SMEs in emerging Asia report that the markets are typically small in scale, with market capitalisation equal to less than $10 \%$ of GDP and market performances that significantly vary by country. In the PRC, both SME Board and ChiNext have been sharply expanding in terms of size and the number of listed companies, with more than 1,000 listed companies in both markets combined, although their growth rates have slowed recently. KOSDAQ and Hong Kong, China's GEM, enjoyed V-shape recoveries from the GFC, but the growth of these markets tends to be slowing with little new listings. The market sizes of Catalist Singapore, ACE Malaysia, and mai Thailand are small compared with similar markets in the PRC and the Republic of Korea, and their listed companies are not increasing at a sufficient pace. This suggests that equity markets in Asia, except for those in the PRC and the Republic of Korea, have not yet become a financing venue for SMEs. Extensive national policies and strategies for improved SMEs access to capital markets are needed.

b) Tax allowances, subsidies and grants: Governments all over the world provide tax holidays and lower tax rates incentive packages and grants to SMEs and startups to defray their costs of production owing to the high initial cost of running them.

c) Less government interference: Governments do as much as they can to stay away from the operations or management of SMEs and startups to enable them express themselves in a market environment to ensure competiveness and efficient allocation of resources in the economy.

d) Venture capital: Venture capitalists take an equity position in companies to help them carry out promising, but higher risk projects. Venture capitalists also expect a healthy return on their investments, often generated when the business starts selling shares to the public. Business owners must be sure to look for investors who bring relevant experience and knowledge to their businesses. 
e) Angels: Angels are generally wealthy individuals or retired company executives who invest directly in small firms owned by others. They are often leaders in their own fields who not only contribute their experience and network of contacts, but also their technical and/or managerial acumen. Angels tend to finance the early stages of businesses.

f) Business incubators: Business incubators (or "accelerators") generally focus on the high-tech sector by providing support for new businesses in various stages of development. However, there are also local economic development incubators, which focus on areas such as job creation, revitalisation, and sharing services. Commonly, incubators will invite future businesses and other fledgling companies to share their premises, as well as their administrative, logistical and technical resources. For example, an incubator might share the use of its laboratories so that a new business can develop and test its products more cheaply before beginning production. Generally, the incubation phase can last up to two years. Once the product is ready, the business usually leaves the incubator's premises to enter its industrial production phase and begins on its own. Businesses that receive this kind of support often operate within state-of-theart sectors such as biotechnology, information technology, multimedia, or industrial technology.

g) Bank loans: Bank loans are the most commonly used source of funding for small and medium enterprises. All banks offer different advantages, whether it is personalised service or customised repayment.

\subsection{Effects of Equity Market Development on Firms}

Capital markets mobilise savings of investors and allocate the funds to listed business entities for investment projects and expansion. In the process of performing these functions, they choose from competing sectors and among competing firms. Stiglitz (1989) is of the view that the form in which firms receive their finance affects how risks get shared, how capital gets allocated, and how firms behave.

Olusoji \& Enofe (2012) report that the incorporation of SMEs into the stock exchange transactions in Nigeria will enhance the growth in the transactions of the capital market in Nigeria. Again, the relaxation of conditions for listing of the SMEs in the stock exchange market and provision of enabling environment for SMEs to thrive in Nigeria will enhance the growth of the Nigerian capital market.

Demirgüç-Kunt \& Maksimovic (1996) empirically analysed the effects of stock market development on firms' financing choices using data from thirty developing and industrial countries from 1980 to 1991 . The results show that initial improvements in the functioning of a developing stock market 
produces a higher debt-equity ratio for firms and thus, more business for banks. In stock markets that are already developed, further development leads to a substitution of equity for debt financing and as a result produces a lower debt-equity ratio. That is, in developing stock markets, large firms become more levered as the stock market develops, whereas small firms do not appear to be significantly affected by stock market development.

Masoud \& Hardaker (2014) provide an empirical investigation into the effect of stock market development, banks development, and firms' growth using Saudi Arabia industrial firm-level data set for the period 1995-2013. The econometric results reveal that with more development in the stock market, firms that used equity finance grew much faster than firms that did not. These findings provide firm-level support for the proposition that the development of the stock market facilitates economic growth. Again, both the stock market and the banking sector development are significant in facilitating firms' growth in Saudi Arabia.

Lagoarde-Segot (2013) investigated whether increases in market-level liquidity had indeed trickled down to individual firms over the last decade of stock market development in Tunisia. The results suggested that massive increases in value traded have created market congestion, thereby increasing the costs of trading, in a context of persistently low efficiency and increased international integration.

The World Federation of Exchanges (WFE, 2014) recognises the importance of ensuring that small and medium enterprises (SMEs) can access equity market financing. The results of surveys of companies, investors and market intermediaries across five developed and emerging market jurisdictions conclude that;

i. A company's decision to list extends beyond a desire to raise finance.

ii. Companies perceive and experience compliance with initial and ongoing listings requirements as burdensome.

iii. Investors would value better quality information about SMEs.

iv. All entities attach importance to secondary market liquidity of a company's shares.

In addition, there are many factors that impact SMEs' use of external finance and their specific financing choices. According to WFE (2014) they include: firm-specific, sector specific determinants, and country-specific factors (such as macroeconomic conditions, the level of financial development or the regulatory framework of the country in which the firm operates).

Companies looking to access external finance consider the associated costs and benefits of a particular financing option. The costs of accessing public equity finance includes the cost of capital (the price at which investors are prepared to provide for the desired funds) and other direct and indirect 
costs associated with being a public listed company. Companies also incur direct and indirect costs to prepare and maintain the listing. The direct costs include: Costs of preparing for the listing-documentation, change in legal status, preparation of relevant documents; costs of sponsor and advisor feesinitial and ongoing; costs of ensuring ongoing compliance (audit fees); admission and on-going fees paid to the exchange. The indirect and more intangible costs include: establishment of requisite governance structures, the opportunity cost of management time spent on ongoing compliance and investor relations; loss/diminution of company control; greater public visibility (accountability), and perceived market short-termism translating into share price volatility. Many of these costs do not depend on the size of the company. Furthermore, underwriting banks, audit firms, legal advisers, etc., are not motivated to support smaller-size companies because it is economically less attractive for them to do so. There is less market share and coverage of small firms that professional investors are less able to make informed investment decisions about them. Their shares tend to be less liquid than the shares of larger companies, providing disincentive to investment and intermediation and driving up the equity cost of capital (WFE, 2014).

There are several benefits of listing on a stock exchange and accessing equity finance. From a financing perspective, given the access to a wider potential investor base, the cost of equity capital can be lower than other forms of finance. Moreover, once listed, secondary offerings are easier to make. WFE (2014) reports that certain types of firms (high growth, and low cash flow firms with limited tangible assets) may not be able to access debt finance (Baldock and Mason, 2015). As equity finance, unlike debt finance, does not impose specific repayment requirements, it is less of a financial burden during times of economic stress. In addition to the specific financing benefits, listing a company also has broader benefits (Pagano, Panetta and Zingales, 1998). It provides existing shareholders with a means of exiting the firm (Bock \& Schmidt, 2015; Mason, 2011). Again, it enhances the profile and prestige of the firm to attract high caliber potential employees, suppliers and clients. Also, it facilitates the use of company shares for future acquisitions through the valuation process.

\subsection{Ghana Alternative Market (GAX)}

In Ghana, GAX has been established to address capital challenges of SMEs and Startups. GAX is a parallel market operated by the Ghana Stock Exchange. It focusses on businesses with potential for growth. The GAX accommodates companies at various stages of their development, including start-ups and existing enterprises, both small and medium. Challenges that confront most SMEs' in Ghana include the following: lack of access to credit facilities, though some financial analysts disagree with this assertion citing 
lack of integrity on the part of owners of SMEs making it difficult for them to access the existing sources of funds provided by banks and microfinance institutions. What probably may be accepted as a justifiable problem in this case is the high interest charges by banks and microfinance institutions. Furthermore, lack of technical and administrative acumen on the part of SME owners, lack of technology to improve their production at a lower cost, as well as many policies of governments having favoured large-scale enterprises to the neglect of SMEs due to tax revenues generated from them have all been mentioned as bane on the growth and development of SMEs and startups.

Listing on GAX has several advantages including:

a. Easier access to long term capital: The raising of such capital allows for future expansion, growth and greater ability to stand competition.

b. Access to long term capital at a relatively lower cost: Advisory and Regulatory fees involved will be lower than that of listing on the main exchange. Securities and Exchange Commission (SEC) guidelines insist on total cost not exceeding $5 \%$ of the total amount to be raised. The listing fee on GAX is also a fixed flat amount.

c. Improvement in the financial position of GAX listed firm: An immediate benefit enjoyed by a GAX listed company is the considerable improvement in its overall financial position. The injection of substantial equity funds, greatly improves the company's balance sheet, given market discipline imposed, and expected improvement in profitability and efficiency of GAX listed firms.

d. Enhanced status in the community: Listing on GAX will raise the level of the investing community's awareness of the existence of the company and its products. This will result in a greater ability to attract high caliber employees, increase demand for the firm's product and general business opportunities.

e. Realisation of value of investments: Owners of companies can also benefit from the realisation of value of their investments when listed on GAX. The market will determine the value of the company and hence original owners can realise the value of their equity in their company.

f. Reduced risk and improved liquidity: GAX will also enable listed businesses to broaden their investor base and provide liquidity for their shareholders or investors.

g. Mandatory underwriting of the minimum offer directly or indirectly by sponsor will result in no failures of Initial Public Offers (IPO); and

h. Companies that list on GAX can apply for funds under GAX-SME listing support fund to pay fully or partly for the cost of advisory services. 
The rules governing GAX are made by the Ghana Stock Exchange with the approval of Securities and Exchange Commission (SEC) in accordance with SEC's powers under the Securities Industry Law, PNDC Law 333 as amended. A company applying to list on GAX must have a minimum stated capital of $\mathrm{GH} \notin 250,000$ (about $\$ 50,000$ ) at the time of listing. A GAX listed company pays an annual fee of $\mathrm{GH} \phi 2,000.00$ (about $\$ 400$ ). The public float of the applicant must constitute a minimum of twenty-five percent $(25 \%)$ of the total number of issued shares. The minimum number of public shareholders shall be twenty (20). Admission may be granted to a start-up company, provided the applicant submits to GAX a 3-year business plan, demonstrating clearly the viability of the applicant's business. The company seeking admission to GAX need not have recorded profits historically, but must have the potential to make profit at least at the end of its third year of listing. Licensed Dealing Members, Investment Advisors or Issuing Houses shall sponsor an application for listing on GAX. Listing and application fees have been waived. A GAX listed company only pays an annual fee of $\varnothing 2,000.00$.

\section{Methodology}

An exploratory quantitative research design was adopted for the study. The quantitative approach centered on data obtained from close-ended and open-ended questionnaires that were conveniently administered to some selected officials of Ghana Stock Exchange, Ghana Alternative Market, Securities and Exchange Commission, Ghana, and brokerage firms who were conveniently selected to complete the questionnaires. The study is underpinned by theories of capital structure of firms. Data collection was done between November, 2018 and March, 2019. A sample size of one hundred and sixty-five respondents (165) was used for analysis. Frequency distribution, bivariate correlations and multiple regression techniques were explored in the study.

(a) The general formula for multiple linear regression is

$\mathrm{Y}=\beta 0+\beta 1 \mathrm{X} 1+\beta 2 \mathrm{X} 2+\ldots+\beta \mathrm{pXp}+\epsilon$

Where, for $\mathrm{i}=\mathrm{n}$ observations:

$\mathrm{Y}=$ dependent variable

$\mathrm{Xi}=$ explanatory variables

$\beta 0=y$-intercept (constant term)

$\beta p=$ slope coefficients for each explanatory variable

$\epsilon=$ the model's error term (also known as the residuals)

The general multiple linear regression model for the study is given as:

$\mathrm{PRGAX}=\beta_{0}+\beta_{1} \mathrm{PU}+\beta_{2} \mathrm{LIP}+\beta_{3} \mathrm{IFF}+\beta_{4} \mathrm{TM}+\beta_{5} \mathrm{LI}+\beta_{6} \mathrm{MF}+\beta_{7} \mathrm{IF}+\beta_{8} \mathrm{UR}$

$+\beta_{9} \mathrm{AIO}+\mathrm{e}$

The model has nine independent variables that are expected to impact negatively on the realisation of the perceived objectives of the Ghana 
Alternative Market (GAX) as they increase. The dependent variable (PRGAX) is the perceived realisation of the objectives of the Ghana Alternative Market. The nine independent (9) factors or variables that were perceived to inhibit the realisation of the objectives of the GAX are: unimportance of GAX by owners of SMEs and Startups as an important avenue to raise financial capital for business investments and growth (PU); the low or moderate level of investor participation in the GAX (LIP); the prospective investors' fear of failure of SMEs and Startups (IFF); the lack of transparency and owners' mismanagement of SMEs and Startups (TM); the low incomes of prospective investors (LI); the domestic macroeconomic factors offering disincentives to prospective investors to buy GAX securities (MF); the inadequate information or awareness of the existence of the GAX among prospective investors (IF); the unattractive returns on GAX securities (UR); and the prospective investors' preferences for alternative investment opportunities (AIO). It is expected that lack of improvement in these factors or variables will have negative influences on the growth and the perceived realization of the objectives of the GAX. The researcher used Statistical Package for the Social Sciences Version 24 to analyse the data collected. The study also estimated correlations of the variables involved. The independence of errors assumption is estimated on the basis of the Durbin-Watson value, and the Variance Inflation Factors (VIF) values for the collinearity assumption is also met. Section 3.1 provides explanations of the independent variables used for the regression analysis.

\subsection{Explanation of Variables}

- Domestic macroeconomic factors offering disincentives to prospective investors to buy GAX securities: Macroeconomic and jurisdiction-specific factors are related to levels of public participation in equity markets. These macroeconomic factors include interest rates, GDP growth, unemployment, inflation, savings, exchange rate, money supply, and the size of the market - liquidity and market capitalisation (World Federation of Exchanges, 2017). Keswani \& Wadhwa (2017) add that economic permanence in a country as measured by macroeconomic variables reveal economic performance in a country and the economic condition will influence the conditions of industries which eventually will affect companies' stock prices. Macroeconomic variables determine the level and direction of investments in a country. The uncertainty of macroeconomic variables affects stock and commodity markets significantly causing volatility in prices. For example, a declining interest rate causes upturns in stock markets. High rate of inflation causes downturns in stock markets, because it signals that interest rates will be rising in the short-term or near future, 
hence slowing economic growth. Rising unemployment foreshadows lower economic growth, and falling unemployment tells stock investors that growth is on the way.

- Lack of transparency and owners' mismanagement of SMEs and Startups: Corporate transparency is important for stock market growth because investors need accurate and complete financial information to make rational investment decisions. Unfortunately, most owners of SMEs and startups find it difficult to make information available to the investing public about the financial position of their firms. To address this challenge, regulatory requirements prescribed by the Securities and Exchange Commissions and Stock Exchanges intend to force businesses to be transparent to some extent by publishing periodic reports for public notification of their business prospects and risks. The stock market works best with accurate information. Management may use the media, internet, investor conferences and other means to educate the investment community about their businesses to instill confidence in the investing public. Senior executives of SMEs and Startups can influence shareholders' interests by providing realistic estimated or actual revenue and profit figures. Stock markets tend to reward firms that demonstrate consistent sales and profit growth by winning investors' confidence, because shareholders' expect to earn dividends and capital gains. Abdelkarim, Shahin, \& Arqawi (2009) investigated the perception of users regarding the availability, adequacy, and usefulness of information disclosed in the financial reports of companies listed on the Palestine Securities Exchange (PSE) and reported that unfavourable perception, along with poor credibility and bad timeliness of disclosures, prevented information from reflecting in stock prices and for that matter investor participation in the stock market.

- Low or moderate level of investor participation in the GAX: UNITAR/DFM (2005) reports that increasing public knowledge and building public confidence in the capital market is central to capital market development because without active continuous public support and participation through mass education and appropriate incentives, capital markets will find it difficult to flourish because of lack of products and liquidity. With little trading, downturns can be magnified, as there is a very thin supply of buyers to begin with and as a result may fail to improve the realisation of stock market objectives and economic growth. Also, the World Federation of Exchanges (2017) writes that retail investors are influenced by emotional and economic factors, and their participation in the stock market may improve the legitimacy and perceived relevance of the market. 
Therefore, stock exchanges seek to encourage the presence and direct participation of retail investors in the market from a market quality perspective as they contribute positively to both market liquidity and resilience which institutional buy-and-hold investors might fail to provide.

- Prospective investors' preferences for alternative investment opportunities and Unattractive returns on GAX securities: Alternative investments are seen to include any investment that is not considered as part of traditional investments. Examples of traditional investments are publicly traded equities, fixed-income securities, and cash. A popular way of distinguishing between traditional and alternative investments is by their expected returns. In another development, investment opportunities showing returns that are substantially distinct from the returns of traditional stocks and bonds might be looked at as alternative investments. An investment opportunity with returns that are uncorrelated with or only slightly correlated with traditional investments is often viewed as an alternative investment. An attractive aspect of this lack of correlation is that it indicates the potential to diversify risk. In this context, many alternative investments are referred to as diversifiers (Kazemi, Black, Anson, \& Chambers (2015).

- Perceived unimportance of GAX by owners of SMEs and startups as an important avenue to raise financial capital for business investments and growth: Owners of SMEs and startups are sometimes said to be equity averse. Equity aversion measures the willingness of a business owner to access equity financing. The main reasons why owners of SMEs and startups do not access the equity market are their fear of losing part of their businesses to others and sharing of control of their businesses with others (Mason \& Kwok, 2010, cited in Tetteh, 2014). Therefore, for such business owners to consider an alternative market for financing that requires its applicants to increase the number of people who share in the ownership or control of their businesses, it is likely that these risk averse entrepreneurs will not list on such a market. This behaviour may be as a result of their lack of access to adequate information on the incentives that the market has to offer and the importance of using alternative forms of financing for the development of businesses (Kadariya et al, 2012, cited in Tetteh, 2014). Therefore to ensure healthy growth of alternative stock markets, owners of SMEs and startups must be educated and informed about the importance of accessing equity financing for development and growth of their businesses (Mason and Kwok, 2010 cited in Tetteh, 2014). They must also be made to understand the incentives that the 
equity financing programmes have to offer. This information will motivate them to list on stock markets.

- Inadequate information or lack of awareness of the existence of the GAX among prospective investors: Studies on determinants of financial markets awareness and participation including Guiso \& Jappelli (2004) conclude among other things that awareness of stocks, bonds, mutual funds, and investment opportunities in financial instruments has a positive relationship with education, households' incomes and wealth, long-term bank relations and social interactions. Alternative stock markets can be successful when managers of stock markets are able to construct appropriate incentive packages that are most likely to attract SMEs, startups, and prospective investors, and communicate these incentive packages to the market players. Policy makers are to ensure that the right information gets to their target groups and the right channels of communication chosen to help reach out to them (Tetteh. 2014). Why do some individuals know about some assets and others not? And what are the mechanisms through which individuals become aware? As Merton (1977) points out that awareness affects asset prices because those that are less widely known, and thus less commonly selected, pay a premium. This makes it worthwhile for firms to invest resources in spreading information about their own stocks (Guiso and Jappelli, 2003).

- Prospective investors' fear of failure of SMEs and Startups: The risk of failure of a startup or an SME is quite high as compared to large companies. It also takes years of hard work to build a new business, despite all this, 70\% do not live long. The early investors in SMEs and startups are also constrained by the limited options when it comes to exiting the company. Buy back by the promoter or scouting for another buyer are the normal options and in such situations the terms of exit may not be very favorable to the investor. Apart from assuming the risk of business failure, the risk of their investment being locked up for very long durations is also one of the constraints faced by these investors in investing in Startups and SMEs. To mitigate risks of investing in startups and SMEs, it is important to list the shares of startups and SMEs on tradable market. The listing would give the startup or SME better visibility and thereby wider reach to investors. With a structured market for investors, SMEs and startups are more likely to easily find investors and also reduce capital costs.

- Low incomes of prospective investors: Guiso, Haliassos and Jappelli (2003) documents a strong positive correlation between stock market participation and household financial wealth in many industrialised countries, supporting the entry costs thesis. But there is also the 
international evidence that many affluent households do not invest in stocks which suggests that other factors than entry costs alone may be at work. Furthermore, the entry cost literature does not explain the origin and nature of these costs. Yet understanding what inhibits stock market participation is crucial for policies aimed at encouraging portfolio diversification and spreading the "equity culture". VissingJorgensen (2002) reports that there are higher trading frequencies for high wealth households. Georgarakos \& Inderst (2011) also add that for households with higher financial capabilities, only the perception of legal protection in financial markets matters for stock market participation.

(a) The correlation coefficient that indicates the strength of the relationship between two variables can be found using the following formula:

$$
\mathbf{r}=\frac{n\left(\sum x y\right)-\left(\sum x\right)\left(\sum y\right)}{\sqrt{\left[n \sum x^{2}-\left(\sum x\right)^{2}\right]\left[n \sum y^{2}-\left(\sum y\right)^{2}\right]}}
$$

Where:

- $r=$ correlation coefficient

- $\mathrm{n}=$ number of observations

- $\mathrm{x}=1^{\text {st }}$ variable in the context

- $y=2^{\text {nd }}$ variable

(b) Confidence interval (CI) estimator.

Where:

$$
\mathrm{CI}=\mathrm{X} \pm \mathrm{Z}\left(\mathrm{s} / \mathrm{V}_{\mathrm{n}}\right)
$$

$\mathbf{X}$ is the mean

$\mathbf{Z}$ is the chosen $\mathbf{Z}$-value from from the standard normal distribution for $95 \%$. $\mathrm{s}$ is the

standard deviation

$\mathbf{n}$ is the number of observations

Note that $\mathrm{SE}=\frac{S}{\sqrt{n}}$

\section{1 $\quad$ Findings}

Table 4.1 shows summary statistics of the relevant variables. It can be seen that the perceived realisation of the objective of GAX is about 3 (Mean $=2.65 ; \mathrm{SD}=0.60$ ), where 3 is the maximum value on the measurement scale. The perceived level of achievability of the target of GAX by the end of 2020 is about 1 (Mean $=0.86$; $\mathrm{SD}=0.01$ ), where 1 is the maximum score on the scale. Apparently, the target of GAX was perceived highly to be achievable by 2020. Similarly, the degree to which the objective of GAX was being 
realised was perceived to be high. Descriptive statistics of the other variables can be seen in the table.

Table 4.1 Summary Statistics of Key Variables

\begin{tabular}{|c|c|c|c|}
\hline Variable & Statistics & Values & $95 \% \mathrm{CI}$ \\
\hline \multirow[b]{2}{*}{ Extent of objective realization } & Mean $^{\mathrm{a}}$ & 2.645 & \pm 2.75 \\
\hline & SD & 0.602 & \pm 0.72 \\
\hline \multirow{2}{*}{ Achievement of target by the end of 2020} & Mean $^{\mathrm{a}}$ & 0.877 & \pm 0.47 \\
\hline & SD & 0.003 & \pm 0.00 \\
\hline \multirow{2}{*}{ Perceived unimportance (PU) } & Mean $^{\mathrm{a}}$ & 0.766 & \pm 0.45 \\
\hline & SD & 0.001 & \pm 0.00 \\
\hline \multirow{2}{*}{ Level of participation (LIP) } & Mean $^{\mathrm{a}}$ & 1.387 & \pm 1.51 \\
\hline & SD & 0.552 & \pm 0.64 \\
\hline \multirow{2}{*}{ Fear of failure (IFF) } & Mean $^{\mathrm{a}}$ & 2.387 & \pm 2.67 \\
\hline & SD & 1.482 & \pm 1.63 \\
\hline \multirow{2}{*}{ Lack of transparency (TM) } & Mean $^{\mathrm{a}}$ & 2.484 & \pm 2.71 \\
\hline & SD & 1.08 & \pm 1.24 \\
\hline \multirow{2}{*}{ Low income (LI) } & Mean $^{\mathrm{a}}$ & 2.677 & \pm 2.95 \\
\hline & SD & 1.361 & \pm 1.48 \\
\hline \multirow{2}{*}{$\begin{array}{l}\text { Macroeconomic factors as a disincentive } \\
\text { (MF) }\end{array}$} & Mean $^{a}$ & 3 & \pm 3.30 \\
\hline & SD & 1.489 & \pm 1.59 \\
\hline \multirow{2}{*}{ Inadequate information (IF) } & Mean $^{\mathrm{a}}$ & 2.484 & \pm 2.77 \\
\hline & SD & 1.442 & \pm 1.59 \\
\hline \multirow{2}{*}{ Unattractive returns (UR) } & Mean $^{\mathrm{a}}$ & 2.548 & \pm 2.82 \\
\hline & SD & 1.298 & \pm 1.44 \\
\hline \multirow{2}{*}{$\begin{array}{l}\text { Preference for alternative investment } \\
\text { options (AIO) }\end{array}$} & Mean $^{a}$ & 2.161 & \pm 2.46 \\
\hline & $\mathrm{SD}$ & 1.424 & \pm 1.58 \\
\hline
\end{tabular}

${ }^{a} \mathrm{n}=165$. Note: $\mathrm{CI}=$ confidence interval; $\mathrm{SD}=$ standard deviation

Table 4.2 shows bivariate correlations of interest. "Extent of objective realisation" is significantly associated with "Achievement of target by the end of 2020" ( $r=0.283 ; p=0.000$; two-tailed), "Perceived importance" of GAX $(\mathrm{r}=0.214 ; \mathrm{p}<0.05$; two-tailed), and "Inadequate information" on GAX ( $\mathrm{r}=$ $0.297 ; p=0.000$; two-tailed), but is not correlated significantly with the other variables at $p>0.05$. These results indicate that the degree to which the objective of GAX is realised was higher for those who thought GAX's target cannot be met by the end of 2020, as compared to those who thought the said target can be met by the designated time. In other words, those who thought that the target of GAX cannot be achieved by 2020 rated the degree to which the objective of the programme was achieved higher than those who thought GAX's target of listing fifty (50) firms can be achieved by the end of 2020. Moreover, the extent to which the objective of GAX is realised increases as perceived importance and inadequacy of information on GAX increase. 
Table 4.2 Bivariate Correlations of Relevant Variables

\begin{tabular}{|c|c|c|c|c|c|c|c|c|c|c|c|c|}
\hline Variables & No. & 1 & 2 & 3 & 4 & 5 & 6 & 7 & 8 & 9 & 10 & 11 \\
\hline Extent of objective realization & 1 & 1 & $.283 * *$ & $.214^{*}$ & 0.01 & -0.086 & 0.196 & -0.074 & 0.057 & $.297 * *$ & -0.075 & 0.073 \\
\hline Achievement of target by the end of $2020^{\mathrm{a}}$ & 2 & & 1 & $.443 * *$ & $-.386 * *$ & $-.254 * *$ & 0.145 & $.216^{* *}$ & -0.022 & -0.041 & -0.048 & -0.155 \\
\hline Perceived unimportance ${ }^{b}$ & 3 & & & 1 & $-.287 * *$ & -0.144 & -0.061 & 0.11 & $-.262 * *$ & -0.063 & -0.007 & -0.13 \\
\hline Level of participation & 4 & & & & 1 & 0.042 & -0.145 & -0.125 & 0.06 & -0.08 & 0.134 & 0.139 \\
\hline Fear of failure & 5 & & & & & 1 & $.491 * *$ & $.333 * *$ & $.467 * *$ & $.623 * *$ & $.582 * *$ & $.671 * *$ \\
\hline Lack of transparency & 6 & & & & & & 1 & $.318^{* *}$ & $.359 * *$ & $.225^{* *}$ & $.373 * *$ & $.307 * *$ \\
\hline Low income & 7 & & & & & & & 1 & $.454 * *$ & $.286 * *$ & $.461^{* *}$ & $.330 * *$ \\
\hline Macroeconomic factors as a disincentive & 8 & & & & & & & & 1 & $.344 * *$ & $.532 * *$ & $.461 * *$ \\
\hline Inadequate information & 9 & & & & & & & & & 1 & $.317 * *$ & $.571 * *$ \\
\hline Unattractive returns & 10 & & & & & & & & & & 1 & $.492 * *$ \\
\hline Preference for alternative investment options & 11 & & & & & & & & & & & 1 \\
\hline
\end{tabular}


Table 4.3 Regression Coefficients and Fit Statistics

\begin{tabular}{|c|c|c|c|c|c|c|c|}
\hline Variable & UC (B) & S.E. & $\mathrm{SC}(\beta)$ & $t$ & $95 \% \mathrm{CI}$ & Tol. & VIF \\
\hline (Constant) & 1.418 & 0.362 & & $3.92 * *$ & \pm 1.44 & & \\
\hline Achievement of target by 2020 & 0.213 & 0.147 & 0.167 & 1.45 & \pm 0.59 & 0.465 & 2.149 \\
\hline Perceived importance & 0.139 & 0.124 & 0.111 & 1.12 & \pm 0.49 & 0.625 & 1.599 \\
\hline Level of participation & 0.173 & 0.107 & 0.159 & 1.62 & \pm 0.43 & 0.640 & 1.561 \\
\hline Fear of failure & -0.407 & 0.082 & -1.000 & $-4.98 * *$ & \pm 0.33 & 0.152 & 6.562 \\
\hline Lack of transparency & 0.158 & 0.055 & 0.284 & $2.88^{*}$ & \pm 0.22 & 0.635 & 1.574 \\
\hline Low income & -0.134 & 0.044 & -0.302 & $-3.06^{* *}$ & \pm 0.17 & 0.631 & 1.584 \\
\hline $\begin{array}{l}\text { Macroeconomic factors as a } \\
\text { disincentive }\end{array}$ & 0.140 & 0.044 & 0.348 & $3.17 * *$ & \pm 0.18 & 0.513 & 1.949 \\
\hline Inadequate information & 0.306 & 0.055 & 0.733 & $5.53 * *$ & \pm 0.22 & 0.352 & 2.839 \\
\hline Unattractive returns & -0.046 & 0.057 & -0.099 & -0.80 & \pm 0.23 & 0.405 & 2.468 \\
\hline $\begin{array}{l}\text { Preference for alternative investment } \\
\text { options }\end{array}$ & 0.145 & 0.062 & 0.344 & $2.36^{*}$ & \pm 0.25 & 0.290 & 3.450 \\
\hline Model fit & & & & & & & \\
\hline $\mathrm{R}^{2}$ & 0.493 & & & & & & \\
\hline Adjusted $\mathrm{R}^{2}$ & 0.431 & & & & & & \\
\hline Change in $\mathrm{R}^{2}$ & 0.062 & & & & & & \\
\hline Durbin-Watson & 1.899 & & & & & & \\
\hline $\mathrm{F}$ & 7.981 & & & & & & \\
\hline $\mathrm{C}_{2}$ & 0.000 & & & & & & \\
\hline
\end{tabular}

In Table 4.3, investors' fear of failure makes a negative influence on the degree to which the objective of GAX is met $(\beta=-1.00 ; \mathrm{t}=-4.98 ; \mathrm{p}=$ $0.000)$, likewise the low-income situation of investors $(\beta=-0.30 ; t=-3.06 ; p$ $=0.000$ ). It is therefore confirmed that the degree to which the objective of GAX is met decreases as investors' fear of failure and low-income situation increases. Interestingly, the degree to which the objective of GAX is met is positively associated with "Lack of transparency" $(\beta=0.284 ; \mathrm{t}=2.88$; $\mathrm{p}<0.05)$, "Macroeconomic factors as a disincentive" $(\beta=0.348 ; \mathrm{t}=3.17 ; \mathrm{p}=$ $0.000)$, "Inadequate information" $(\beta=0.733 ; \mathrm{t}=5.53 ; \mathrm{p}=0.000)$ and "Preference for alternative investment options" $(\beta=0.344 ; \mathrm{t}=2.36 ; \mathrm{p}<0.05)$. Interestingly, the findings mean that the degree to which the objective of GAX is met increases as these inhibitory factors increase. The regression model accounted for a variance of $49.3 \%$, an adjusted variance of $43.1 \%$, and a significant $\mathrm{F}$-test $(\mathrm{F}=7.981, \mathrm{p}=0.000)$. The independence of errors assumption is met on the basis of the Durbin-Watson value being approximately 2 . On the basis of the tolerance and VIF values, the collinearity assumption is also met. This is the case because none of the criterion variables has its Variance Inflation Factors (VIF) to be more than 10. Should that have happened, the problem of multicollinearity would have been more likely. Multicolliniarity is a phenomenon in which two or more predictor variables in 
a multiple regression model are highly correlated in which case the coefficient estimates of the multiple linear regressions may change erratically in response to small changes in the model or the data.

The study reveals that fear of failure of SMEs and low incomes of prospective investors are the most important factors likely to hinder the growth and realisation of the objectives of the GAX. The main findings of the study is supported by Wanyana (2011) who wrote that the way an investor behaves in the financial (stock) market depicts his perceived risk attitudes about the available stocks hence affecting the trading of stocks and investor portfolio selection.

Guiso \& Jappelli (2004) wrote that the extent to which consumers or investors are aware of available financial assets depends on the incentives of asset suppliers to spread information about the instruments they issue.

Vissing-Jorgensen (2002) reports that there are higher trading frequencies for high wealth households. Also, even if incomes of people were to increase, people's participation in the capital market will on the other hand depend on the legal protection they are offered by the capital market. Georgarakos \& Inderst (2011) also add that for households with higher financial capabilities, only the perception of legal protection in financial markets matters for stock market participation. The capital market can provide adequate legal protection for investors by training lawyers in capital market issues to defend the interest of investors.

\section{Summary, Conclusions and Recommendations \\ 5.1 Summary and Conclusions}

Small and medium enterprises and start-ups supposed lack of access to financial capital for operation led to the establishment of the GAX, though some financial analysts disagree with this assertion, citing lack of integrity on the part of owners of SMEs making it difficult for them to access the existing sources of funds provided by banks and microfinance institutions. What probably may be accepted as a justifiable problem, in this case is the high interest charges by banks and microfinance institutions. Like the GAX, many similar markets on the African continent and equity markets in Asia have struggled to attract SMEs' and startups' listings.

This study sought to explore the factors that inhibit the realisation of the perceived objectives of GAX and the target of listing fifty (50) firms by the end of year 2020 as well as the correlates of the factors,. The bivariate correlations of interest show that "Extent of objective realisation" is significantly associated with "Achievement of target by 2020", "Perceived importance of GAX", and "Inadequate Information on GAX. Those who thought that the target of GAX cannot be achieved by the end of 2020 rated the degree to which the objective of the programme was achieved higher than 
those who thought GAX's target can be achieved by the end of 2020. Also, as inhibitory factors, the degree to which the objective of GAX is met decreases as investors' fear of failure and low-income situations of prospective investors increase.

\subsection{Recommendations}

The GAX authorities must intensify education on the importance of the GAX to business owners and the security of prospective investors' investments in businesses that would be listed on the GAX. This will help increase public awareness and the perceived importance of GAX and improve information on the GAX. On public education, the exchange must go all length to hold radio and television discussions to disabuse the minds of prospective investors about the perceived fear of failure of SMEs and startups. The GAX authorities and government agencies must develop governance education and guidance programmes for all directors of SMEs, with potential to list, in an effort to enhance their managerial competence.

Employees must be paid well and encouraged to invest in securities to secure their retirements and to promote the growth of GAX and businesses to create more job opportunities for the unemployed in the society.

Government should consider offering tax incentives for listed SMEs and investors investing directly in listed SMEs' securities. Providing grants for listed firms to cover listing costs could be of great benefit to the growth of SMEs ans startups. Grants will help defray the cost Initial public offerings (IPO).

Interestingly, the degree to which the objective of GAX is met is positively associated with "Lack of transparency", "Macroeconomic factors as a disincentive", "Inadequate information", and "Preference for alternative investment options". This section of the results deviates from our expectations and it may probably be attributed to data management and questionnaires responses problems. We recommend more investigations into these variables that produced contrary results in the estimated model, so as to create a pool of findings and information for the development of GAX.

To enable business firms access capital there must be dedicated public and private sector participants. This requires that management improves infrastructure, market linkage formation, promotional support service, public education, corporate governance and transparency, innovation and business development, increased networking opportunities, and improvement of advisory services.

The government of Ghana must find the possibility of synchronizing the activities of National Entrepreneurship and Innovation Plan (NEIP), Microfinance and Small Loans Centre (MASLOC) and GAX to reduce 
duplication of effort and to ensure efficient allocation of financial resources to small scale businesses and startups.

\section{References:}

1. Abdelkarim, N., Shahin, A. Y., \& Arqawi, M. B. (2009). Investor perception of information disclosed in financial reports of Palestine securities exchange listed companies. Accounting \& Taxation, Volume 1, Number 1.

2. Aduda, J., Masila, M. J., \& Onsongo, N. E. (2012). The determinants of stock market development: The case for the Nairobi stock exchange. International Journal of Humanities and Social Science, Vol. 2 No. 9. Retrieved on $22^{\text {nd }} \quad$ February 2013, from http://www.ijhssnet.com/journals

3. African Securities Exchanges Association (ASEA, 2017). Capital raising opportunities for small and medium enterprises $\left(\mathrm{SME}_{\mathrm{S}}\right)$ on stock exchanges in Africa. https://africanexchanges.org/sites/default/files/publications/capital_raising_opportu nities_for_smes_on_stock_exchanges_in_africa.pdf

4. Business Development Bank of Canada. Seven (7) sources of start-up financing.https://www.bdc.ca/en/articles-tools/start-buybusiness/start-business/pages/start-up-financing-sources.aspx. Retrieved on $4^{\text {th }}$ July, 2018

5. Bortey, N. I. (2013, 24 October). The Ghana alternative market (GAX) and the development of SMEs in Ghana. Modern Ghana.

6. Bruce, E. (2018; 13 ${ }^{\text {th }}$ March). Three companies to list on GAX this year. Graphic Business News Online

7. Collier, S. T. (2014). Five steps that create inclusive growth through SMEs. The Broker. http://www.thebrokeronline.eu/

8. Darko, B. (2017). SMEs need integrity more than capital. Business and Financial Times, Tuesday, October 17, 2017, page 7.

9. Demirgüç-Kunt, A., \& Maksimovic, V. (1996). Stock market development and financing choices of firms. The World Bank Economic Review Vol. 10, No. 2, A Symposium Issue on Stock Markets and Economic Development (May, 1996), pp. 341-369: Oxford University Press (http://www.jstor.org/stable/3990066)

10. Demirgüç-Kunt, A., \& Maksimovic, V. (1996). Stock market development and corporate finance decisions. Finance \& Development / June 1996. Retrieved on 12 $12^{\text {th }}$ July, 2018 from https://www.imf.org/external/pubs/ft/fandd/1996/06/pdf/demirguc.pd f, pp. 46-49

11. Edem, S. (2017). Ghana's National Entrepreneurship \& Innovation Plan. 
12. Edmiston, D. K. (2004). "The role of small business in economic development," Community Affairs Research Working Paper 2005-01, Federal Reserve Bank of Kansas City.

13. El-Wassal, A. K (2013). The development of stock markets: In search of a theory. International

14. Journal of Economics and Financial Issues, Vol. 3, No. 3, 2013, pp.606-624. ISSN: 2146-4138 www.econjournals.com

15. Griffiths, A, S Stuart, W. (1995). Applied economics: An introductory Course. $6^{\text {th }}$ ed.. Singapore:Longman Singapore Publishers (Ptc) Ltd.

16. Georgarakos, D., \& Inderst, R. (2011). Financial advice and stock market participation. European Central Bank, working paper series no 1296. Retrieved on June, 2013 from http://www.ecb.europa.eu/pub/pdf/scpwps/ecbwp1296.pdf

17. Ghana Stock Exchange (2013). Ghana Alternative Market (GAX) Rules.https://gse.com.gh/readfile?file=https:/gse.com.gh/docs/2013/ GHANA\%20ALTERNATIVE\%20MARKET\%20\%20GAX\%20Rules\%20-\%20February\%202013.pdf; retrieved on $27^{\text {th }}$ June, 2018.

18. GAX to list 50 companies by 2020. goldstreetbusiness.com, $12^{\text {th }}$ March, 2018.

19. Guiso, L. \& Jappelli, T. (2004). Awareness and stock market participation. Centre for

20. Studies in Economics and Finance (CSEF), Working Paper No. 110. Retrieved on August, 2019, from http://www.csef.it/WP/wp110.pdf

21. Harwood, A., \& Konidaris. T. (2015). SME exchanges in emerging market economies: A stocktaking of development practices. Policy Research Working Paper 7160. Finance and Markets Global Practice Group, World Bank Group.

22. Kazemi, H., Black, H. K., Anson, J. P. M., \& Chambers, R. D. (2015). Alternative Investments:

23. CAIA Level I, 3rd ed., CAIA Association, J Hoboken, New Jersey: John Wiley \& Sons

24. Keswani, S., \& Wadhwa, B. (2017). Effect of macroeconomic variables on stock market: A

25. conceptual study. International Journal of Management, IT \& Engineering. Vol. 7 Issue 10, http://www.ijmra.us.

26. Lagoarde-Segot, T. (2013). Does stock market development always improve firm-level financing? Evidence from Tunisia. Research in International Business and Finance, Volume 27, Issue 1, January 2013, Pages 183-208 
27. Masoud, N., \& Hardaker, G. (2014). Stock market development, banks and firms growth: empirical evidence from Saudi Arabia. American Journal of Finance and Accounting. Retrieve from: https://www.researchgate.net/publication/264812159_Stock_market_ development_banks_and_firms_growth_empirical_evidence_from_S audi_Arabia (on July 12, 2018).

28. Nkuah, K. J., Tanyeh, P. J., \& 3 Gaeten, K. (2013). Financing Small and Medium Enterprises

29. (SMEs) in Ghana: Challenges and determinants in accessing bank credit. International Journal of Research in Social Sciences. Vol. 2, No.3, www.ijsk.org/ijrss.

30. OECD (2005). OECD SME and Entrepreneurship Outlook: 2005, OECD Paris, page 17.

31. Olusoji, O. M., \& Enofe, E. E. (2012). Capital market and the development of the small and medium- scale enterprises in Nigeria. .IOSR Journal of Business and Management (IOSR-JBM) ISSN: 2278-487X. Volume 5, Issue 4 (Nov. - Dec. 2012), PP 05-12

32. Shinozaki, S. (2014). Capital market financing for SMEs: A growing need in emerging Asia.ADB Working Paper Series on Regional Economic Integration, Asian Development Bank, Publication Stock No. WPS136176.

33. Sitharam, S. \& Hoque, M. (2016). Factors affecting the performance of small and medium enterprises in KwaZulu-Natal, South Africa. Journal of Problems and Perspectives in Management, 14(2-2), 277288. doi:10.21511/ppm.14 (2-2).2016.03

34. Stiglitz, E. J. (1989). Financial markets and development. Oxford Review of Economic Policy,Vol 5, No. 4. Retrieved from https://www.unicef.org/spanish/socialpolicy/files/Financial_Markets_ and_Development.pdf on 12 the July, 2018).

35. Tetteh, D. (2018). One-man type of businesses' urged to open-up for investment. Business and Financial Times, April 24, 2018.

36. Tetteh, M. (2014). SMEs financing: Investigating why the Ghana alternative stock market

37. (GAX) has not attracted listings. A dissertation submitted to the Department of Business Administration, Ashesi University College.

38. Teye, S. K. (2013). Have you considered the Ghana alternative market (GAX)? Business News of Wednesday, 19 June 2013.

39. UNITAR/DFM (2005). Online course on fundamentals of capital market development and regulation. Capital market development training and capacity building programmes in debt and financial management.. United Nation Training Institute 
40. UNITAR/DFM (2005). Online course on capital market development and regulation (advance course). Capital market development training and capacity building programmes in debt and financial management.. United Nation Training Institute

41. Vissing-Jorgensen, A. (2002). Towards an explanation of household portfolio choice heterogeneity: Nonfinancial income and participation cost structures. The National Bureau of Economic Research (NBER) Working Paper No. 8884, 1050 Massachusetts Avenue, Cambridge, MA 02138. Retrieved on April, 2013, from http://www.nber.org/papers/w8884

42. Wanyana, B. (2011). Investor awareness, perceived risk attitudes, and stock market investor behaviour: A case of Uganda securities exchange. A master's dissertation, Makerere University. Retrieved on September, 2013 from http://www.mubs.ac.ug/docs/masters/mbi/Investor

43. World Federation of Exchange (2014). Financing and equity markets. www.world-exchnages.org.

44. World Federation of Exchanges (2017). Enhancing retail participation in emerging markets.www.world-exchanges.org. Retrieved from https://www.worldexchanges.org/storage/app/media/research/Studies _Reports/WFE\%20Enhancing\%20Emerging\%20Market\%20Retail\% 20Trading\%20Report\%20-\%203\%20August\%202017.pdf on $17^{\text {th }}$ October, 2017.

45. World Bank (2002). Building institutions for markets. World Development Report 2002. Oxford; Oxford University Press.

46. https://www.investopedia.com/ask/answers/031915/what-capitalstructure-theory.asp, retrieved on 3/07/2018

47. http://www.managementstudyguide.com/capital-structure.htm\#, retrieved on $3 / 07 / 2018$

48. Business Development Bank of Canada. 7 sources of start-up financing.https://www.bdc.ca/en/articles-tools/start-buybusiness/start-business/pages/start-up-financing-sources.aspx. Retrieved on $4^{\text {th }}$ July, 2018

49. https://corporatefinanceinstitute.com/resources/knowledge/other/smal 1-and-medium-sized-enterprises-smes/ Retrieved on $3^{\text {rd }}$ October, 2019 